\title{
BACTERIOCIN TYPING OF STAPHYLOCOCCI
}

\author{
B. SKALKA \\ Department of Microbiology and Immunology, \\ University of Veterinary and Pharmaceutical Sciences, 61242 Brno
}

Received fuly 10, 1992

\begin{abstract}
Skalka, B.: Bacteriocin Typing of Staphylococci. Acta vet. Brno, 61, 1992: 179-187.

The report describes bacteriocin typing of staphylococcal strains using the deferred method. The collection of active strains comprised 11 strains, 9 of which were isolated by the author, namely $3 S$. intermedius strains, $2 S$. hominis strains and 1 strain each of $S$. epidermidis, $S$. simulans, $S$. sciuri and $S$. haemolyticus, and two additional strains, namely $S$. aureus producing bacteriocin $B a c R_{1}$ and $S$. simulans biovar staphylolyticus. The active strains varied in spectrum and intensity of their effects on both indicator stains and examined strains. Using the active strains a total of 2083 staphylococcal strains representing a great majority of known staphylococcal species were typed. The highest sensitivity was shown by coagulase-positive species, lower sensitivity was found in coagulase-negative, novobiocin-sensitive species and the lowest sensitivity was found in coagulase-negative, novobiocin-resistant species. The bacteriocin typing described in the report may prove useful for detailed characteristics of staphylococcal strains.
\end{abstract}

Bacteriocin typing, deferred method, Staphylococcus spp., active strains, indicator strains, examined strains

Our previous reports on antibiotic products of staphylococci have described the characteristics of bacteriocins, also called staphylococcins, bacteriocin-like substances, together with information on their frequency within the genus Staphylococcus and their application in presumptive bacteriocin typing of staphylococci (Skalka 1985, 1986a, 1986b). Till now practical utilization of staphylococcins and staphylococcin-like staphylococcal antibiotic substances has been limited to laboratory studies in spite of some solitary descriptions of their successful clinical use in staphylococcal infections (Lachowicz 1965, Gerber and Nowak 1976) and in the therapy of a skin disease of Dermatophilus congolensis aetiology (Zaria 1991). Laboratory use of staphylococcin producers has been described by Ivanov (1970, Jetten and Vogels (1972), Pulverer and Jeljaszewicz (1976) and S Smarda and Obdržálek (1981). The object of the present study is to present our own set of active strains and its use in bacteriocin typing of staphylococcal species.

\section{Materials and Methods}

\section{Nutrient Media}

Brain Heart Infusion Agar CM 375 (Oxoid) and Blood Agar Base No. 4 (Imuna) were used.

\section{Bacterial Strains}

Bacterial strains were divided into the following three groups: a set of active strains or producers of antibiotic substances, a set of known indicator strains and a set of strains to be examined. The identification of staphylococci and the biotyping of $S$. aureus were carried out on the basis of generally accepted recommendations (Devriese 1984, Kloos and Schleifer 1986).

The list of active and indicator strains gives their working designation (W), species, original laboratory designation (L) and Collection code (C). 
Active Strains

W Species

1 S. simulans

biov. staphylolyticus

$2 S$. aureus biov. A

$4 \quad$ S. intermedius

$5 \quad S$. intermedius

$6 \quad$ S. epidermidis

8 S. hominis

14 S. hominis

$14 S$. intermedius

16 S. simulans

22 S. sciuri

23

S. haemolyticus

Indicator Strains

a Corynebacterium renale

b C. pseudodiphtheriticum

c S. aureus biov. C

d S. aureus biov. C

e $\quad S$. aureus biov. C

f $\quad S$. aureus biov. C

g S. intermedius

h S. intermedius

i S. haemolyticus

$\mathrm{k} \quad S$. epidermidis
L

K6 WI

C

CCM 3583.

UTO002
OP-42
OP-12
K-14
KONT-40
KONT-32
NO 66
N 99
KPJ III
KO VI

Mau 87/79

M 23/85

M 24/85

M $25 / 85$

M 34/86

M 31/86

M $29 / 85$

M 30/86

M 32/86

$-$

С̆B 27

C1-0

ČB II 66

ČB II 45

OP-41

P-274

KONT 33

St 2

Strain 1 is known by its production of lysostaphin (Schindler and Schuhardt 1964) and strain 2, by its production of bacteriocin Bac $R_{1}$ (Warren et al. 1974). The remaining strains for bacteriocin typing were isolated in our laboratory. Of these only strain 23 is not deposited in any collection. CCM strains are deposited in the Czechoslovak Collection of Microorganisms and M, Mau Psdi strains are deposited in the Czechoslovak National Collection of Type Cultures (CNCTC) and their characteristics are listed in the Catalogues of the two collections (Kocur et al. 1982, Šourek 1990).

\section{Staphylococcal Strains Examined}

A total of 2083 strains of the genus Staphylococcus were examined. The set included 511 S. aureus strains (of these 104, 98 and 309 represented biovar A, biovar B and biovar C, respectively), 114 $S$. intermedius strains, $206 S$. hyicus strains, 103 S. chromogenes strains, 115 S. epidermidis strains, $102 S$. haemolyticus strains, $94 S$. simulans strains, 84 S. warneri strains, 96 S. hominis strains, 192 S. saprophyticus strains, 105 S. cohnii strains, 135 S. xylosus strains, 72 S. gallinarum strains, $115 S$. sciuri strains, 8 S. caprae strains, $6 S$. carnosus strains, 6 S. capitis strains, $6 S$. equorum strains, $4 S$. auricularis strains, $4 S$. arlettae strains, $3 S$. kloosii strains and $2 S$. lentus strains. None of the tested strains was antibiotically active on the indicator strains used in the study. $S$. aureus biovar A strains were kindly provided by the Microbiological Department, Faculty of Medicine, Masaryk's University, Brno, and the remaining strains were isolated from farm animals in the author's laboratory (Skalka 1991).

\section{Bacteriocin Typing Technique}

The technique of pre-cultivation of active strains (deferred method) with their subsequent devitalization with chloroform vapour and spraying of a suspension of the tested or known indicator strain was used in most strains of the set of producers of antibiotic substances. Only in strain 2 whose bacteriocin $B a c R_{1}$ is sensitive to chloroform a modification consisting in cultivation of "lawn bands" was employed. Details of the technicue were reported nreviously (Skalka 1986a, 1986b).

\section{Results}

The collection of active strains for typing was asembled on the basis of comparison of the effects of more than 250 presumptively identified producers of antibiotic substances. To 9 strains isolated in our laboratory the following two 
generally known strains were added: strain 1 producing lysostaphin and strain 2 producing bacteriocin $B a c R_{1}$. The set of staphylococcal indicator strains, to which two corynebacteria were added, was assembled on the basis of our previous experience.

Table 1

Antibiotic effects of strains of the set for bacteriocin typing on indicator strains

\begin{tabular}{|c|c|c|c|c|c|c|c|c|c|c|}
\hline $\begin{array}{l}\text { Active } \\
\text { strains }\end{array}$ & $\mathbf{a}$ & b & c & d & $\underset{\mathrm{e}}{\text { Indicato }}$ & r strains & $\mathbf{g}$ & $\mathbf{h}$ & $\mathbf{i}$ & $\mathbf{k}$ \\
\hline $\begin{array}{r}1 \\
\mathbf{2} \\
4 \\
\mathbf{4} \\
\mathbf{5} \\
\mathbf{6} \\
\mathbf{1 0} \\
10 \\
14 \\
16 \\
\mathbf{2 2} \\
.23\end{array}$ & $\begin{array}{r}++\overline{+} \\
+ \\
++ \\
++ \pm \\
\overline{+} \\
\pm \\
++ \pm\end{array}$ & $\begin{array}{r}+\overline{+} \\
+ \\
+ \\
+++ \\
\overline{-} \\
++ \\
+\end{array}$ & $\begin{array}{r}t+t \\
++t \\
++t \\
+++ \\
+++ \\
++ \\
++ \\
+++ \\
+++ \\
++t \\
+++\end{array}$ & $\begin{array}{r}+++ \\
+++ \\
+++ \\
+++ \\
+++ \\
++ \\
+ \\
+++ \\
+++ \\
+++ \\
+++\end{array}$ & $\begin{array}{r}+++ \\
+++ \\
+++ \\
+++ \\
+++ \\
++ \\
++ \\
+++ \\
+++ \\
+++ \\
+++\end{array}$ & $\begin{array}{r}t++ \\
+++ \\
++ \\
+++ \\
+++ \\
++ \\
++ \\
++ \\
++ \\
+++ \\
+++\end{array}$ & $\begin{array}{r}++ \pm \\
\pm \\
+ \\
\pm \\
\pm \\
++ \\
+++ \\
+++ \\
+++\end{array}$ & $\begin{array}{r}t+ \\
= \\
++ \\
++ \\
= \\
= \\
++ \\
+++ \\
+++\end{array}$ & $\begin{array}{r}++ \pm \\
= \\
\pm \\
\pm \\
++ \\
+ \\
+++ \\
++ \pm\end{array}$ & $\begin{array}{r} \pm \\
\pm \\
++ \\
+ \\
+ \\
+ \\
++ \\
++\end{array}$ \\
\hline
\end{tabular}

Legend: For explanation of the figures designating active and indicator strains see Materials and Methods. Evaluation of the width of the inhibition zone from the margin of the colony:

$-=$ no effect, $+=$ less than $2 \mathrm{~mm},++=2 \mathrm{~mm}$ to $5 \mathrm{~mm},++=$ more than $5 \mathrm{~mm}$

Strain 22 showed the widest spectrum and the highest intensity of activity on all the indicator strains. Only a slightly weaker intensity of the effects on some indicator strains was seen in strain 6. Strains 1 and 16 exerted marked antibiotic effects on both coagulase-positive and coagulase-negative staphylococcal indicators but proved inactive on both corynebacteria. Strain 23 produced marked inhibition of coagulase-positive staphylococcal indicators but had negative effects on coagulase-negative and corynebacterial indicators. Strains 2 and 4 showed a similar spectrum of activity, the effects of strain 2 on the two corynebacteria being more intense. Strain 5 was intensely active towards $S$. aureus indicators and had a weaker effect on $S$. intermedius, coagulase-negative staphylococci and on the two corynebacteria. Strain 14 exerted intense effects on most coagulase-positive. indicators, weak effects on coagulase-negative indicators and no effect on corynebacterial indicators. Strain $\mathbf{8}$ and $\mathbf{1 0}$ were the least effective of the active strains. The spectra and intensity of the effects on the active strains are shown in Table 1.

The sensitivity of the staphylococci examined varied from species to species and particularly from strain to strain. The inhibition of growth of a tested strain manifested by a zone greater than $2 \mathrm{~mm}$ in diameter round the spot of the active strain was scored as a positive effect; differences in its intensity were not included in the final evaluation. All coagulase-positive strains were sensitive to lysostaphin of strain 1, whereas the sensitivity of coagulase-negative strains was about $50 \%$, being highest in $S$. chromogenes strains and lowest in $S$. sciuri strains. Sensitivity to Bac $R_{1}$ of strain 2 was characteristic of $S$. aureus while $S$. intermedius and all strains coagulase-negative strains were resistant and only a small number of $S$. hyicus strains were sensitive. $S$. aureus and $S$. intermedius strains were highly sensitive to strains 6, 16 and 22 while the sensitivity of $S$. hyicus and all coagulase-negative strains to exosubstances of these strains ranged from $30 \%$ to $85 \%$. Antibiotic substances of strains $\mathbf{4}$ and $\mathbf{5}$ exerted effects on $S$. aureus biovar strains, which represented the group of the sensitivity, and on about $50 \%$ of $S$. intermedius strains and on only a small number of the remaining staphylococci under study. 


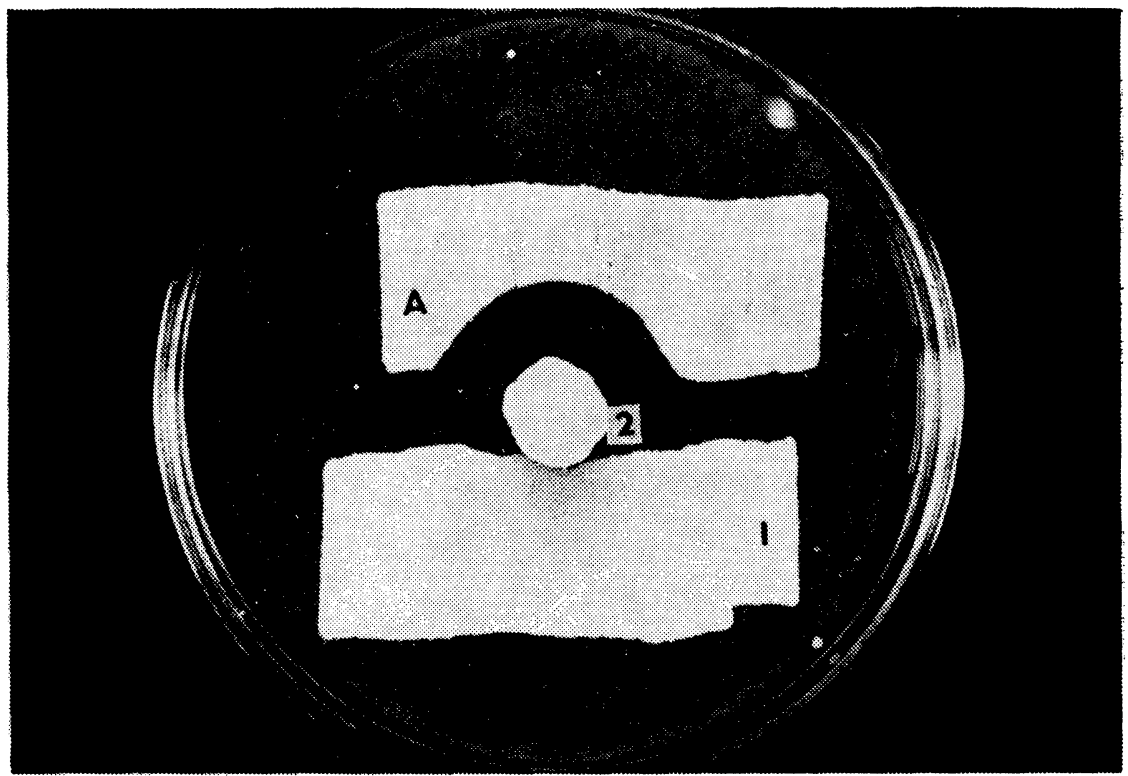

Fig. 1. Tests of the sensitivity of $S$. aureus biovar $\mathrm{C}(\mathrm{A})$ and $S$. intermedius (I) strains to Bac $\mathbf{R}_{\text {, }}$ of strain 2 (2).

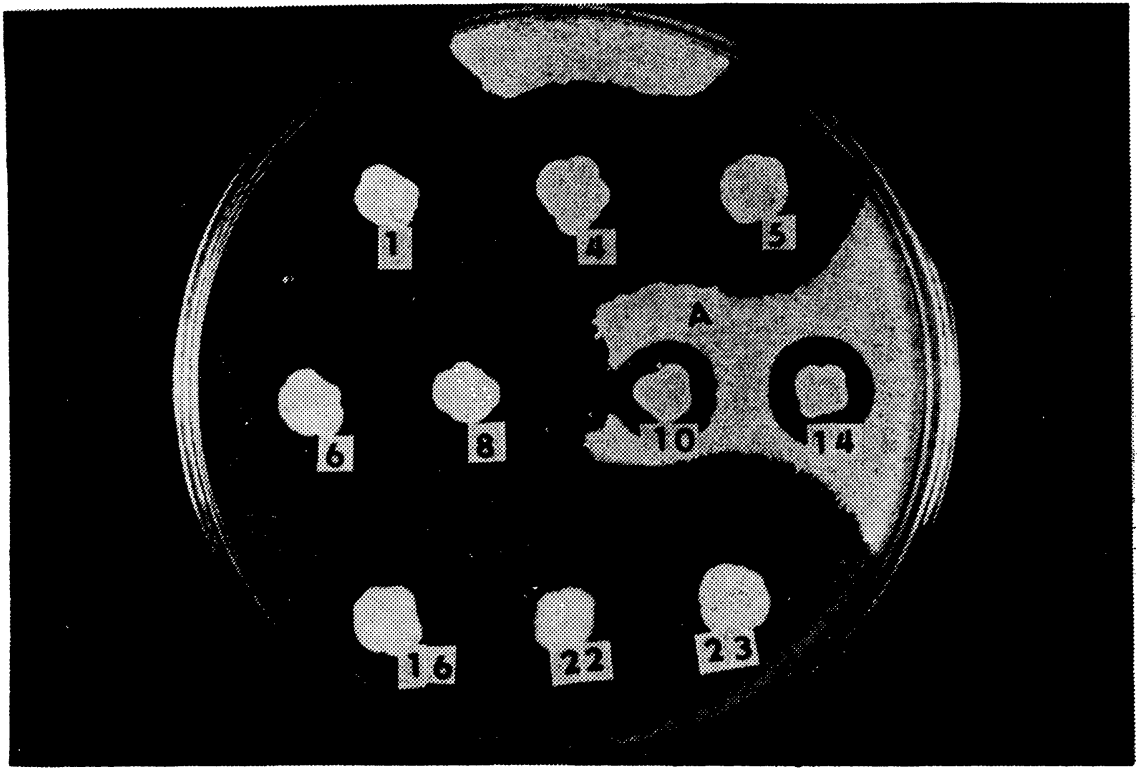

Fig. 2. Result of bacteriocin typing of $S$. aureus biovar C strain (A). For explanation of the figures designating active strains see Materials and Methods. 


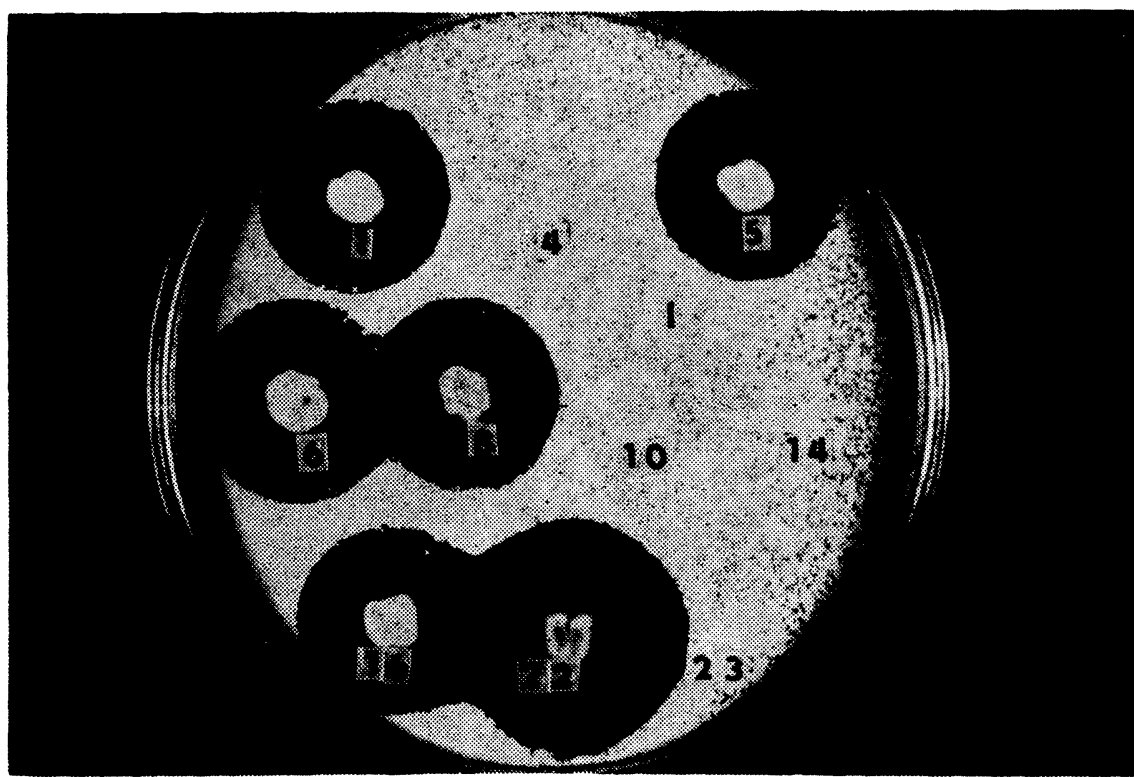

Fig. 3. Result of bacteriocin typing of $S$. intermedius strain (I). For explanation of the figures: designating active strains see Materials and Methods.

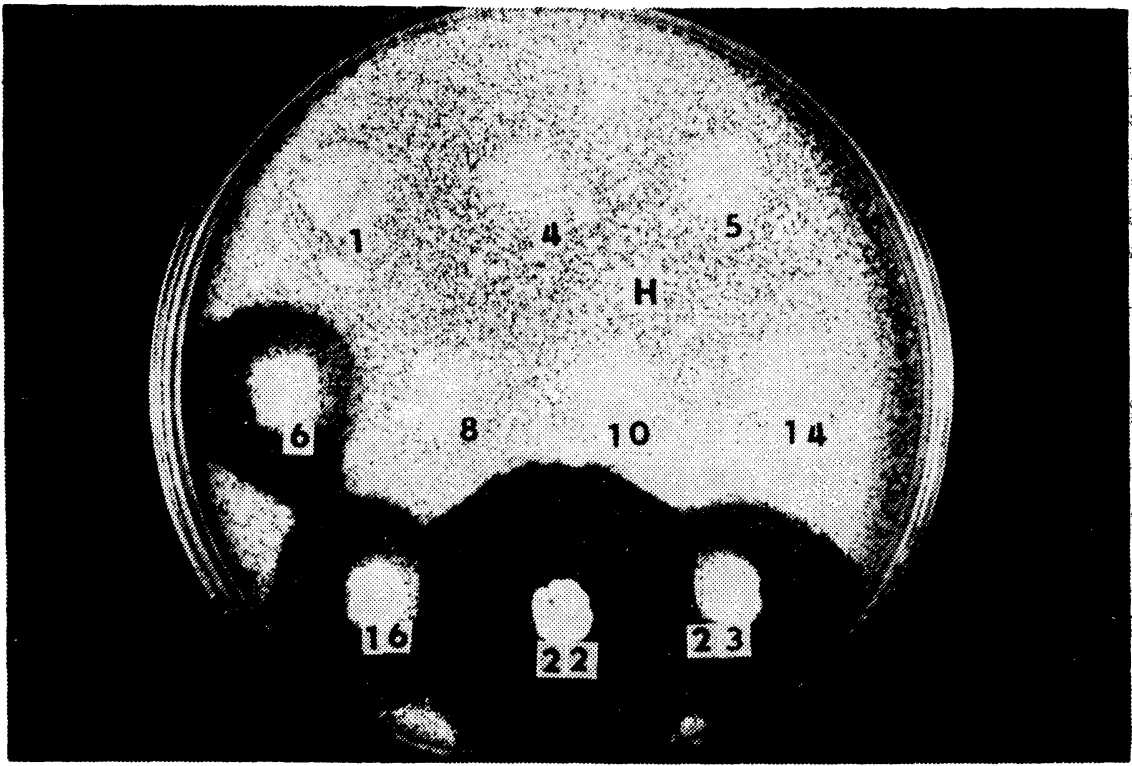

Fig. 4. Result of bacteriocin typing of $S$. haemolyticus strain $(\mathrm{H})$. For explanation of the figures. designating active strains see Materials and Methods. 
Strain 23 inhibited the majority of $S$. aureus strains, had less effect on $S$. chromogenes, $S$. hyicus and $S$. intermedius strains, little effect on coagulase-negative, novobiocin-sensitive staphylococci and no effect on coagulase-negative, novobiocin-resistant staphylococci. Relatively narrow spectra of effects were shown by exosubstances of strains 8,10 and 14. From total assessment of the results it appears that the highest sensitivity was shown by coagulase-positive strains, a much weaker sensitivity was recorded for coagulase-negative, novobiocin-sensitive strains and the lowest sensitivity was shown by coagulase-negative, novobiocin-resistant strains, particularly by $S$. sciuri. Complete resistance was shown by less than $5 \%$ of the strains examined. Within species there were groups sharing the same character of sensitivity. The results are illustrated by 4 examples in Fig. $1-4$ and summarized in Table 2 . S. carnosus, $S$. caprae, $S$. auricularis, $S$. capitis, $S$. equorum, $S$. arlettae, $S$. kloosii and $S$. lentus were not included in the table because of their low numbers. Their sensitivity, however, was similar to that of coagulase-negative staphylococci.

Table 2

Results of bacteriocin typing of staphylococci under study in terms of \% sensitivity

\begin{tabular}{|c|c|c|c|c|c|c|c|c|c|c|c|c|}
\hline $\begin{array}{l}\text { Staph. } \\
\text { spec. }\end{array}$ & N. & 1 & 2 & 4 & 5 & 6 & $\begin{array}{c}\text { Active s } \\
8\end{array}$ & 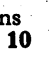 & 14 & 16 & 22 & 23 \\
\hline $\begin{array}{l}\text { aur } \mathbf{A} \\
\text { aur B } \\
\text { aur C } \\
\text { int } \\
\text { hyi }\end{array}$ & $\begin{array}{r}104 \\
98 \\
309 \\
114 \\
206\end{array}$ & $\begin{array}{l}100 \\
100 \\
100 \\
100 \\
100\end{array}$ & $\begin{array}{r}100 \\
100 \\
100 \\
0 \\
5\end{array}$ & $\begin{array}{r}2 \\
6 \\
100 \\
45 \\
10\end{array}$ & $\begin{array}{r}4 \\
8 \\
100 \\
56 \\
13\end{array}$ & $\begin{array}{r}100 \\
100 \\
100 \\
100 \\
53\end{array}$ & $\begin{array}{r}2 \\
18 \\
52 \\
8 \\
16\end{array}$ & $\begin{array}{r}2 \\
12 \\
15 \\
14 \\
16\end{array}$ & $\begin{array}{r}9 \\
16 \\
40 \\
5 \\
8\end{array}$ & $\begin{array}{r}100 \\
98 \\
100 \\
100 \\
68\end{array}$ & $\begin{array}{r}100 \\
98 \\
100 \\
100 \\
79\end{array}$ & $\begin{array}{l}70 \\
62 \\
88 \\
47 \\
35\end{array}$ \\
\hline $\begin{array}{l}\text { chr } \\
\text { epi } \\
\text { hae } \\
\text { sim } \\
\text { war } \\
\text { hom }\end{array}$ & $\begin{array}{r}103 \\
115 \\
102 \\
94 \\
84 \\
96\end{array}$ & $\begin{array}{l}89 \\
64 \\
47 \\
52 \\
58 \\
52\end{array}$ & $\begin{array}{l}0 \\
0 \\
0 \\
0 \\
0 \\
0\end{array}$ & $\begin{array}{r}10 \\
2 \\
0 \\
3 \\
5 \\
3\end{array}$ & $\begin{array}{r}12 \\
3 \\
0 \\
3 \\
5 \\
6\end{array}$ & $\begin{array}{l}60 \\
58 \\
35 \\
64 \\
58 \\
71\end{array}$ & $\begin{array}{r}13 \\
22 \\
5 \\
14 \\
12 \\
7\end{array}$ & $\begin{array}{l}8 \\
5 \\
3 \\
2 \\
6 \\
4\end{array}$ & $\begin{array}{r}4 \\
13 \\
2 \\
0 \\
5 \\
4\end{array}$ & $\begin{array}{l}72 \\
33 \\
76 \\
66 \\
74 \\
58\end{array}$ & $\begin{array}{l}76 \\
71 \\
79 \\
81 \\
83 \\
86\end{array}$ & $\begin{array}{r}41 \\
5 \\
6 \\
2 \\
6 \\
3\end{array}$ \\
\hline $\begin{array}{l}\text { sap } \\
\text { coh } \\
\text { xyl } \\
\text { gal } \\
\text { sci }\end{array}$ & $\begin{array}{r}192 \\
105 \\
135 \\
72 \\
115\end{array}$ & $\begin{array}{l}46 \\
44 \\
48 \\
43 \\
26\end{array}$ & $\begin{array}{l}0 \\
0 \\
0 \\
0 \\
0\end{array}$ & $\begin{array}{l}0 \\
0 \\
0 \\
0 \\
0\end{array}$ & $\begin{array}{l}1 \\
1 \\
3 \\
1 \\
0\end{array}$ & $\begin{array}{l}65 \\
69 \\
64 \\
61 \\
48\end{array}$ & $\begin{array}{l}6 \\
5 \\
6 \\
3 \\
1\end{array}$ & $\begin{array}{l}0 \\
0 \\
6 \\
1 \\
0\end{array}$ & $\begin{array}{l}0 \\
0 \\
2 \\
4 \\
0\end{array}$ & $\begin{array}{l}38 \\
33 \\
32 \\
28 \\
31\end{array}$ & $\begin{array}{l}79 \\
86 \\
84 \\
83 \\
81\end{array}$ & $\begin{array}{l}0 \\
0 \\
0 \\
0 \\
0\end{array}$ \\
\hline
\end{tabular}

Legend: $\mathrm{N}=$ number of strains, aur $=S$. aureus, $\mathrm{A}, \mathrm{B}, \mathrm{C}=$ biovar, hyi $=S$. hyicus, int $=S$. intermedius, chr $=S$. chromogenes, epi $=S$. epidermidis, hae $=S$. haemolyticus, sim $=S$. simulans, war $=S$. warneri, hom $=S$. hominis, sap $=S$. saprophyticus, coh $=S$. cohnii, $x y l=S$. xylosus, gal $=S$. gallinarum, $\mathrm{sci}=S$. sciuri For explanation of the figures designating active strains see Materials and Methods

\section{Discussion}

Our previous studies (Skalka 1986a, 1986b) enabled us to assemble both a collection for bacteriocin typing of staphylococci and a collection of indicator strains. Combined with our experiences with exfoliatin producers (Skalka et al. 1983a, $1983 \mathrm{~b}$ ), the afore-mentioned studies made it possible to use Bac $R_{1}$ producer and two corynebacterial indicators. In the light of the reports on the possibility of differentiating staphylococci and micrococci by means of lysostaphin (Poutrel and Caffin 1981, Baker 1984, Geary and Stevens 1986, Harvey and Gilmour 1988) we extended our collection of active strains by including the producer of this enzyme complex.

In spite of attempts at uniform terminology in the field of bacteriocins the respective suggestions along this line have not been accepted by some writers 
(Piard and Desmaud 1992). For the most part, however, the recommendation has been accepted that bacteria-produced antibiotic substances should be termed bacteriocins or bacteriocin-like substances depending on as to how they meet the classical criteria (Tagg et al. 1976). Except lysostaphin of strain 1 and bacteriocin Bac $R_{1}$ the antibiotic substances of the remaining strains of our active set meet the criteria required for bacteriocin-like exosubstances.

The results obtained with the typing set strains on indicator strains show that the set comprised strains having a wide spectrum and a high intensity of activity along with strains producing weaker effects. However, the inclusion of the latter contributed to the achievement of greater differentiation of typed staphylococci.

From the results obtained with lysostaphin producer it appears that the concentration of this enzyme complex achieved upon the growth of the producer on nutrient medium was not sufficient to affect all staphylococci, particularly those coagulase-negative, which agrees with the observations reported by Poutrel and Caffin (1981). Investigators who used commercial disks having a high concentration of this exosubstance described 100 per cent effects (Geary and Stevens 1986, Harvey and Gilmour 1988), but they tested mainly $S$. aureus strains. Baker (1984) who studied the sensitivity of a wider spectrum of staphylococcal species to commercial lysostaphin disks found a high resistance in $S$. haemolyticus, S. warneri and S. epidermidis strains.

The finding that the effect of bacteriocin Bac $R_{1}$ was limited only to $S$. aureus strains corresponds to our previous experience (Skalka 1986b).

The activity of the remaining strains of the bacteriocin set as assessed on tested strains correlated with the results of their testing on known indicators. Of particular interest are great effects of strains 4 and 5 on $S$. aureus biovar $\mathrm{C}$ and $S$. intermedius, considering their weak activity on the other $S$. aureus biovar strains on the strains of the remaining staphylococcal species, also described previously (Skalka 1968b). However, we have not succeded as yet in obtaining antibiotic strains the effect of which would be reciprocal to the effects of strains 6 and 23, i. e. the effects of which would be higher on coagulase-negative staphylococci and weak on those coagulase-positive.

From the results reported here it appears that the strains most sensitive to the set of active strains used in our study were those of $S$. aureus biovar C, followed by $S$. intermedius and $S$. aureus biovar A and biovar B strains. Much weaker sensitivity was shown by coagulase-negative strains, particularly by those resistant to novobiocin. In the present study the results of bacteriocin typing of the strains examined do not give the degree of intensity of the effects of active strains as used in testing on the indicators. Such assessment, possibly extended to include further degrees of intensity is recommendable for routine bacteriocin typing.

Comparison of the present results with those reported by other writers is difficult considering the use of different active strains and different numbers of strains examined and, last but not least, the changes in the taxonomy of staphylococci. Our observations on the sensitivity of staphylococci as a whole correspond to those of Ivanov (1970) and our findings of higher sensitivity of coagulase-positive strains are in keeping with the data reported by Pulverer and Jeljaszewicz (1975) and Smarda and Obdržálek (1981). Higher sensitivity of coagulase-negative than coagulase-positive staphylococci was reported by Jetten and Vogels (1972) but only for the sensitivity to staphylococcin 1580.

The bacteriocin typing of staphylococci described in the present report is feasible in terms of cost, well-suited for detailed characteristics of strains and 
may prove useful in epizootic and epidemic studies. An analogous method has been recommended for a similar purpose also in other gram-positive species (Watson 1985).

\section{Bakteriocinotypizace stafylokoků}

Realizovala se bakteriocinotypizace kmenů stafylokokových druhů použitím metody předkultivace. Aktivní soubor byl tvořen $11 \mathrm{kmeny}, \mathrm{z}$ nichž 9 bylo izolováno autorem, a to $3 S$. intermedius, $2 S$. hominis, po jednom kmeni $S$. epidermidis, $S$. simulans, $S$. sciuri, $S$. haemolyticus, dále dvěma doplňujícími kmeny, a to $S$. aureus produkujícim bakteriocin $B a c R_{1}$ a $S$. simulans biovar staphylolyticus. Kmeny aktivního souboru měly různé spektrum a intenzitu efektů na souboru indikátorových kmenů i na vyšetřovaných kmenech. Celkem bylo aktivním souborem typizováno 2083 stafylokokových kmenů, náležejících do převážné většiny známých stafylokokových druhů. Nejvyšší citlivost se zjistila u druhů koagulázapozitivních, nižší u druhủ koagulázanegativních novobiocin senzitivních a nejnižši u druhů koagulázanegativních novobiocin rezistentních. Popsaná bakteriocinotypizace se jeví jako vhodná metoda pro detailnější charakteristiku stafylokokových kmenú.

\section{Бактериоцинотипизация стафипококков}

Проводили бактериоцинотипизацию штаммов стафилококовых видов с применением метода предварительного культивирования. Активный комплекс состоял из 11 штаммов, девять из них было изолировано автором, а именно $3 \mathrm{~S}$. intermedius, $2 \mathrm{~S}$. hominis, по одному штамму $S$. epidermidis, $S$. simulans, $S$. sciuri, S. haemolyticus, далее, двүмя дополнительными штаммами, а именно $S$. aureus, производящим бактериоцин Bac $R_{1}$ и $S$. simulans биовар staphylolyticus. Штаммы активного комплекса отличались разным спектром и интенсивностью эффектов на комплексе индикаторных штаммов и на исследуемых штаммах. В итоге типизировали активным комплексом 2083 стафилококковых штаммов, в преобладающем большинстве принадлежащих к известным стафилококковым видам. Самая большая чувствительность была установлена у коагулаза положительных видов, более низкая - у коагулаза негативных новобиоцин чувствительных и самая низкая - у коагулаза негативных новобиоцин резистентных видов. Приведенное описание бактериоцинотипизации является пригодным методом с целью достижения более детальной характеристики стафилококковых штаммов.

\section{References}

BAKER, J. S.: Comparison of various methods for differentiation of staphylococci and micrococci. J. Clin. Microbiol., 19, 1984: 875-879.

DEVRIESE, L. A.: A simplified system for biotyping Staphylococcus aureus strains isolated from different animal species. J. Appl. Bacteriol., 56, 1984: 215-220.

GEARY, C. - STEVENS, M.: Rapid lysostaphin test to differentiate Staphylococcus and Micrococcus species. J. Clin. Microbiol., 23, 1986: 1044-1045.

GERBER, R. - NOWAK, J.: Treatment of chronic staphylococcal osteomyelitis with Staphylococcin A (STA). Zbl. Bakt. Hyg. I. Abt., Suppl. 5, 1976: 1131-1134. 
HARVEY, J.-GILMOUR, A.: The use of a multipoint inoculation method to perform lysostaphin, lysozyme and glycerol-erythromycin tests for the differentiation of staphylococci and micrococci. Letters in Appl. Microbiol., 6, 1988: 109-111.

IVANOV, N. A.: Staphylococcins, their properties, classification, and use for typing of staphylococci. Bull. Exp. Biol. Med., 69, 1970: 559-560.

JETTEN, M. A.-VOGELS, G. D.: Nature and properties of a Staphylococcus epidermidis bacteriocin. J. Bacteriol., 112, 1972: 243-250.

KLOOS, W. E. - SCHLEIFER, K. H.: Genus IV. Staphylococcus Rosenbach 1884, s. 1013 to 1035. In: SNEATH, P. H. A. - MAIR, N. S. - SHARPE, M. E.-HOLT, J. G.: Bergey's manual of systematic bacteriology, Vol. 2. Baltimore, London, Los Angeles, Sydney. Williams and Wilkins. 1986. p. 965-1595.

KOCUR, M. - PÁCOVÁ, Z. - SOVADINA, M.: Catalogue of Cultures. Bacteria. Brno. Czechoslovak Collection of Microorganisms. 1982. $213 \mathrm{p}$.

LACHOWICZ, T.: Investigations on staphylococcins. Zbl. Bakt. Hyg. I. Abt. Orig. A 196, 1965: $340-351$.

PIARD, J. C. - DESMAZEAUD, M.: Inhibiting factors produced by lactic acid bacteria. 2. Bacteriocins and other antibacterial substances. Lait, 72, 1992: 113-142.

POUTREL, B.-CAFFIN, J. P.: Lysostaphin disk test for routine presumptive identification of staphylococci. J. Clin. Microbiol., 13, 1981: 1023-1025.

PULVERER, G. - JELJASZEWICZ, J.: Staphylococcal micrococcins. Zbl. Bakt. Hyg. I. Abt., Suppl. 5, 1976: 599-621.

SCHINDLER, C. A.- SCHUHARDT, V. T.: Lysostaphin: a new bacteriolytic agent for the Staphylococcus. Proc. Natl. Acad. Sci. USA, 51, 1964: 414-421.

SKALKA, B.: Staphylococcal bacteriocins - their present and perspectives (orig. in Czech). Veterinářství, 35, 1985: 316-317.

SKALKA, B.: Bacteriocin activity of Staphylococcus aureus, Staphylococcus intermedius and coagulase-negative staphylococcal strains. Acta vet. Brno, 55, 1986a: 65-72.

SKALKA, B.: Typing of Staphylococcus aureus, Staphylococcus intermedius and coagulase-negative staphylococci by means of staphylococcal bacteriocins. Acta vet. Brno, 55, 1986 b: $333-342$.

SKALKA, B.: The incidence of Staphylococcus species in clinically healthy farm animals (orig. in Czech). Veter. Med. (Praha), 36, 1991: 9-19.

SKALKA, B. - PILLICH, J.-POSPIŚIL, L.: New possibilities of staphylococcin detection in the exfoliatin-producing strains of Staphylococcus aureus. Zbl. Bakt. Hyg., I. Abt. Orig. A 254, 1983a: 34-41.

SKALKA, B. - PILLICH, J.-POSPÍŠIL, L.: Further observations of Corynebacterium renale as an indicator organism in the detection of the exfoliation positive strains of Staphylococcus aureus. Zbl. Bakt. Hyg. A 256, 1983b: 168-174.

ŠMARDA, J.- OBDRŽÁLEK, V.: Staphylococcins: Incidence and some characteristics of antibiotic action. Zbl. Bakt. Hyg. I. Abt. Suppl. 10, 1981: 407-411.

ŠOUREK, J.: Catalogue of pathogenic microorganisms. The Czechoslovak National Collection of Type Cultures. 1990. Prague. $134 \mathrm{p}$.

TAGG, J. R.-DAJANI, A. S.-WANNAMAKER, L. W.: Bacteriocins of gram-positive bacteria. Bacteriol. Rev., 40, 1976: 722-756.

WARREN, R.-ROGOLSKY, M.-WILEY, B. B.-GLASGOW, L. A.: Effect of ethidium bromide on elimination of exfoliative toxin and bacteriocin production in Staphylococcus aureus. J. Bacteriol., 118, 1974: 980-985.

WATSON, G. N.: The assessment and application of a bacteriocin typing scheme for Clostridium perfringens. J. Hyg. Camb., 94, 1985: 69-79.

ZARIA, L. T.: In vitro and in vivo inhibition of Dermatophilus congolensis by coagulase-negative antibiotic producing staphylococci from pigs. Res. Vet. Sci., 50, 1991: 245-246. 